\title{
Austerity, inequality and the context of contemporary social work
}

\author{
Michael Lavalette ${ }^{1}$
}

\begin{abstract}
This paper provides an overview of the contemporary context of austerity politics in the U.K. Austerity acts as a cover for welfare transformation and public sector spending reductions. The consequence has been to deepen inequality and make the lives of the poorest and marginalised much more difficult. Understanding these processes is important for social workers if we are to fully comprehend the difficulties placed on service users and their already complex lives.
\end{abstract}

Keywords: austerity, inequality, poverty, wealth

1. Professor, Dept of Social Work, Care and Justice, Liverpool Hope University

Address for correspondence: Dept of Social Work, Care and Justice, Liverpool Hope University L16 9JD, UK. lavalem@hope.ac.uk 
What Michael Roberts (2016) calls the 'long depression' of the early twenty-first century shows no signs of ending. Financial instability and low economic growth continue to have an impact on global economic performance. In response to this crisis large units of capital and states across the globe have been involved in a concerted attempt to reduce living standards, for the majority, as a means or restoring profitability across the system. This has been enshrined in policies of 'austerity', the claim that we can no longer afford what is thought of as the 'post-war welfare settlement' and that, as a result, 'there is no alternative' to savage cuts and welfare restructuring.

'Austerity', is a political and economic project geared towards reducing government public sector social spending and was presented as an inevitable consequence of the 2007/2008 financial crisis. That crisis started in the US 'sub-prime' housing sector. Due to a lack of investment in, and lack of provision of, social housing poor families were, in effect, forced to buy homes they could not afford. Financial institutions provided mortgages and loans to poor families based on the assumption that house prices inevitably rise and so, if families defaulted on their loans, their homes would be re-possessed and sold on by banks for a profit - leaving the poor homeless and indebted. (Robbins 2017)

By the turn of the twenty-first century, however, this model started to go badly wrong. Banks and lending companies found themselves with increasing amounts of bad debt, which they in turn bundled up and sold on through the financial system to Hedge Funds and various financial interests. The bad debt spread through-out the system, until, in 2007, the system fell like a pack of cards (Harman 2009). Banks were deemed 'too big to fail', so vast state resources were ploughed in to save the banks, creating vast pools of state debt. In the UK the financial assistance provided to the banks resulted in the national debt in the UK rising to $£ 850$ billion, enough to pay for the now supposedly inflated National Health Service for more than 8 years (Mendoza 2015). Quantitative easing and low interest rates were advocated as ways to stimulate the economy and improve growth levels - but they have failed to do so (Ferguson et al 2017).

It is worth reminding ourselves that the immediate cause of the current depression was catastrophic failures in the banking and financial systems because, for ten years in Britain, successive Governments have tried to explain the crisis by reference to over-generous welfare, helping to create an 'anti-welfare common-sense' that has reinforced stigma on the very poorest in our communities (Jensen and Tyler 2015). Pressures on public services and benefit payments and the scarcity of better job opportunities has been blamed on excessive immigration and freeloading welfare 'dependents' while the financial system has largely escaped any serious critique.

To repay the debt, successive Governments have launched year-after-year cuts in public sector funding. These have led to reduced local authority spending on public services (Asthana 2017), have severely cut welfare benefit spending (Ryan 2017), have reduced resources in the housing, health and educational spheres (IFS 
2015) - in turn leading to work intensification for public sector workers (Ellis 2017) and led to a significant tightening in living standards (Wright and Case 2017). The direct impact of austerity can be seen in recent work done by Fitzpatrick et al (2016) for the Joseph Rowntree Foundation which found that about 1.25 million people in the UK are currently living in destitution where they are unable to buy the essentials needed to eat, remain warm and ensure personal hygiene. It is the politics of austerity that has led to the appalling institutionalisation of food banks within the UK welfare state (Garthwaite 2016). Harrop and Reed (2015) estimate that 2 million more children in England will be living in poverty by 2030, if current policy trajectories remain the same.

Austerity has produced declining living standards for the majority, but it has been particularly acute for some of the most vulnerable communities in society. To look at this in more detail we need to consider the impact of a number of mutually reinforcing sets of changes including those in the labour market, welfare state reform and rising costs of basic goods, such as housing.

\section{Labour market changes}

Deteriorating pay is part of a longer term downward pressure on wages and working conditions associated with successive attempts to realise 'flexible' labour markets (Lansley and Mack 2015; Mendoza 2015). However, this process has consolidated further under austerity. The Enterprise and Regulatory Reform Act passed in 2013 is a prime example of the buttressing of insecure and precarious working patterns through amendments to current employment legislation (Mendoza 2015: 126-7). Part of this deregulation in the labour market has been the huge rise in the number of employees working in what are informally known as 'zero hour contracts'. The possibility for employment relations to be organised along this line has existed for decades but the sharp rise under austerity reveals some of the coordinated ways in which other policies are imposing precarity. The Resolution Foundation (2013) found that people on zero hour contracts have a lower gross weekly pay of $£ 236$ compared to those not on zero hours which is $£ 482$ per week. The Office for National Statistics (2014) reported that some 1.4 million workers were in contractual arrangements which had no guaranteed hours. Other changes to the labour market which are emblematic of the normalising of casualised, temporary and insecure work include the rise in low paid self-employment (Lansley and Mack 2014), relatively low skill apprentice schemes with no guaranteed end job (Ofsted 2015), cuts in public sector pay (O'Hara 2015) and the return of totally unpaid employment through Mandatory Work Placements. The impact of this collection of reforms is increasing financial insecurity. John Hills's (2015) recent research aimed to break down the pervasive myth of a workless, unemployed and welfare-dependent population, and presents 
evidence of the extent to which those at the bottom of the income structure have to juggle a number of different work commitments and require (insufficient) welfare support to plug gaps in periods of unemployment, lack of access to satisfactory hours and changing caring responsibilities and family structure. Economic insecurity has also been organised through transformations in the forms of support available from the welfare state. Mary O'Hara described the support available to people with longer term needs as 'a complex package of discriminatory reforms' (2015: 145). It is worth drawing out two pillars of this assemblage of reforms that are producing a decline in living standards. Firstly, disentitling strategies embodying new forms of means testing are attempting to strip people of existing benefit payments. Secondly, there is a more generalised programme of cuts to direct financial benefits including reductions in Jobseeker's Allowance, the removal of the Independent Living Fund and Disability Living Allowance and the moves towards the introduction of Universal Credit (O'Hara 2015, p.158).

\section{Housing}

Housing has also become a topic mired in controversy and is central to understanding rising living costs in Britain. Through long term and tandem processes of disinvestment in state-driven social housing programmes (Mendoza 2015: 58-59) and the financialisation of the housing market in England (New Economics Foundation 2016, Minton 2016) problems of rising rent and limited supply of housing define the current market. In 2015 , house prices rose by $4.5 \%$ while average pay only increased 2\% (Meyer and Stuart 2015). Coupled with this generalised crisis in costs and supply, there has been the introduction of the 'under occupancy charge', more commonly known as the 'bedroom tax', for households where there are 'extra' bedrooms in social housing. This has forced many households in social housing to give back part of their benefit derived income to the state if there are more bedrooms than occupants in a given property, or it has forced them to move from their home into a house in the private rented sector (which costs more and has resulted in an increase in housing benefit costs).

Under the guise of austerity, the post-2008 governments have deliberately orchestrated a set of labour market and welfare reforms which impose new forms of financial insecurity and deprivation onto households and individuals. As a result, people are being forced to turn to the debt and personal financing industry based on exorbitant interest rates and catering for the needs of low income individuals who have insecure, fluctuating and unpredictable pay packets. Indebtedness has been shown to have a complex interrelationship with anxiety and depression (Davies et al 2015). 


\section{Health and social care}

If we just take mental health services as an example we can see the impact that austerity has on various sets of provisions.

Recent research by Community Care and the BBC obtained freedom of information requests from 43 of the 56 Mental Health Trusts in England revealing a reduction in funding of $8.25 \%$ in real terms (McNicoll 2015). In cash terms, the amount has diminished from $£ 6.7 \mathrm{bn}$ in 2010-11 to an estimated $£ 6.6 \mathrm{bn}$ in 2014-15. The same research has shown that community mental health teams have seen a funding decrease of $5 \%$. The numbers of beds in mental health hospitals has also diminished. The Care Quality Commission recently warned that Approved Mental Health Practitioners (AHMPs) are being put under extreme pressure due to a lack of beds. Andy McNicoll reported that the total number of beds in mental health hospitals that have been closed since is April 2011 and 2014 is 2100 (McNicoll 2014). Mental health hospitals in some trusts are running at $120 \%$ capacity, despite the Royal College of Psychiatrists recommending an occupancy rate of 85\% (RCPsych 2011). There have even been seven suicides and one homicide directly linked to a lack of beds in hospital facilities (McNicoll 2014a).

Under the Mental Health Act in England, people can be detained in hospitals against their will if they are deemed to be a risk to themselves or others. Data from the Health and Social Care Information Centre (quoted by McNicoll 2014b) showed that in 2015 these detentions were up by 10\% from the previous year, with some suggesting that professionals were resorting to enforced detentions in order to find patients hospital beds (BBC 2015). Pressures on treatment services have meant that a breakdown in a person's mental health has become a more frightening and traumatic experience. Not only have hospitals become overcrowded but Trusts are increasingly resorting to out-of-area treatment options (Buchanan 2014). This involves transporting people experiencing a downward spiralling situation in their mental health, sometimes hundreds of miles, to other facilities.

In the UK, social care and health care are separate policy fields with distinct modes of operation, legislative frameworks and funding sources. Social care is geared towards catering for longer term illness or disability. Whilst healthcare is largely funded through central taxation, social care is financed through local councils who raise taxes within their region and receive a proportion of funding from central government. Health and social care provision, therefore, is affected by cuts to both the NHS and to local authority budgets.

Since the start of austerity UK local council budgets have been seriously affected. But these cuts have not been applied uniformly, indeed, it has been the most economically deprived councils which have suffered the biggest cuts. A recent study found that social care spending from 2010 to 2015 in the most well off councils has actually risen by $8 \%$ whilst it has fallen by $14 \%$ in the most economically deprived (Hastings et al 2015). 
To take Liverpool as an example, it remains one of the poorest cities in Britain (Department for Communities and Local Government 2015) with the latest child poverty rates indicating $32.1 \%$ of children in the city live in poverty (the majority in working households). Yet Liverpool has experienced exceptional reductions in central government funding. By 2017 Liverpool City Council will have had to make $£ 329$ million in savings which represents a 58\% cut in funding in real terms since 2010 (Brindle 2015).

Yet the cuts in mental health funding is running in tandem with transformations in how the nature of mental health support is viewed in terms of its aims, scope and foundational principles. Austerity has proved to be a convenient economic cover for promoting ideological changes. For instance, reductions in funding for community care can be neatly accompanied with more individualised interventions. Previous services have often delivered ongoing support in day centres, day hospitals and other community settings which could last months and even years. This sort of service created opportunities for long term care for those with persistent mental health problems (Bell 2013). Yet many of these services are being replaced with alternative short-term provision with an emphasis on 'recovery'. Hospitals and day centres are moving services towards short-term recuperation models where patients are asked to resolve, often long term mental health problems, in very small periods of time. There is also an individualising undercurrent to these transformations, where selfrecovery and independence are valued above other possible views on how mental health services should be delivered. This 'responsibilisation' agenda seems to fit neatly with the context of declining funding (Brown and Baker 2012). A model of mental health where full recovery is not only possible, but is also best achieved by the individual taking responsibility for their own health legitimates reducing or even eliminating the network of community based professionals and services.

Austerity has left vulnerable communities (those we work alongside in social work) living marginalised and perilous lives. But austerity has not been bad for everyone. As Garsdie (2015) notes, the wealthiest have seen their wealth grow exponentially during the recession.

Each year, the Sunday Times produces an annual 'Rich List' which plots the wealth of the 1000 wealthiest people in the UK. The Table below shows the growth in their wealth over the period the Rich List has been running (1989 to the present). It emphasises the huge increase in the wealth of the wealthiest over the last 27 years in the UK - a period which has seen the UK become one of the most unequal societies in the world (Dorling 2017). The Table shows that whilst the wealthiest did see their wealth dip immediately after the crisis of 2007/08 it didn't take them long to recover - unlike the majority in Britain who continue to find themselves worse off than when the crisis hit (Stewart 2015, Hamilton 2017).

The richest $10 \%$ of UK population now control $45 \%$ of wealth while the bottom half of the economic strata control a meagre 8.7\% (Office for National Statistics 2015). 


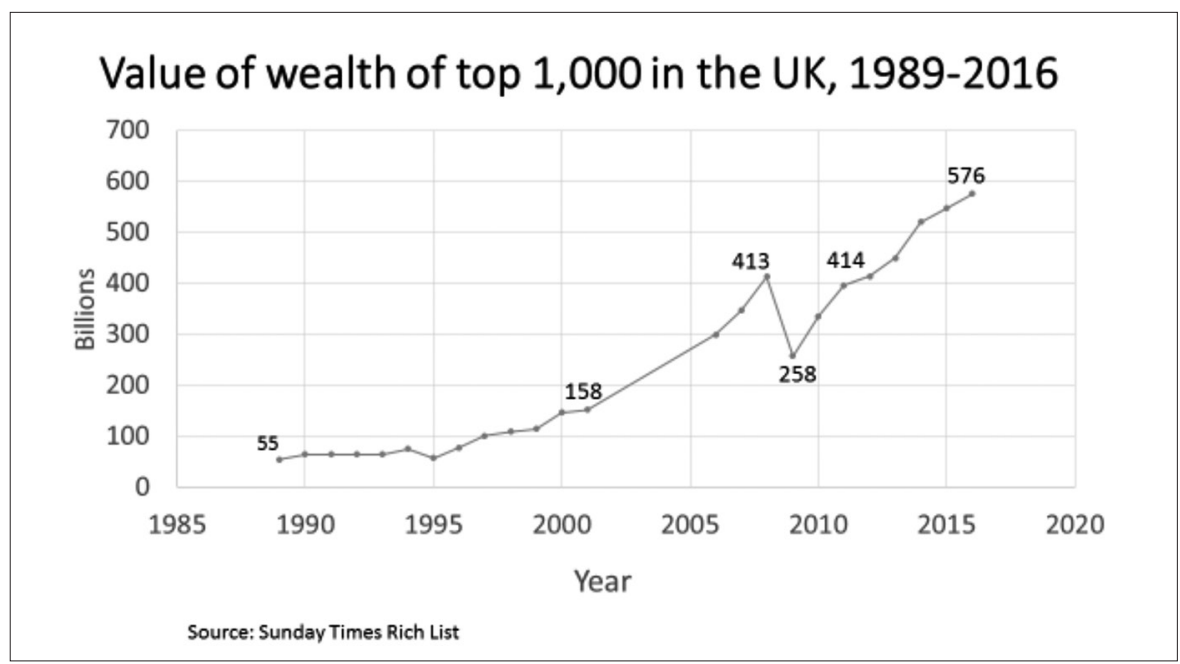

Not surprisingly, growing inequality, reduction in public services and an oftendivisive political narrative has been accompanied with a general decline in levels of trust in political institutions in the UK and across Europe. For example, in 2007 across the EU, 57\% of people claimed that they generally trusted the European Institutions whilst in 2013 this had fallen to only 31\% (Eurobarometer 2013). In the UK, trust in the EU was only 19\% in 2013. Distrust in both EU institutions and in national political processes has also arguably set the context for potentially the biggest political event to happen in the UK for decades: when the British public voted to leave the EU.

It is in this context of political crisis, rising inequality, reductions in spending on public sector services, mass welfare transformation and an insidious political discourse that forms the background to many of the articles presented in this special edition of Social Work and Social Sciences Review. For social workers it is imperative that we understanding the impact of austerity on the lives of service users and recognise the enforced changes it is bringing to public and welfare services. But it is also the case that austerity is being used to transform the social work labour process, to institutionalise managerialism within services and turn social workers into rationers of care. The essays in this issue offer an essential starting point to considering and confronting these processes and thinking about what the future may hold for state social work.

\section{References}

Asthana, A (2017) Council funding freeze means cuts to many essential services. The Guardian 21 February 2017 www.guardian.co.uk/society/2017/feb/21/lack-council- 
funding-essential-services-slashed (accessed 30 August 2017)

Bell, D. (2013) Mental Health and its Treatment Today. Centre for Health and the Public Interest (CHPI)

Brindle, D. (2015) Liverpool council faces stark choices as it looks into the financial abyss, The Guardian, 10 November

Brown, B.J., and Baker, S. (2012) Responsible Citizens: Individuals, health and policy under neoliberalism. London: Anthem Press

Buchannan, M. (2014) Mental health patients forced to travel miles for care , BBC, 6 May

Davies, W., Montgomorie, J., and Wallin, S. 2015. Financial Melancholia: Mental health and indebtedness. London: Goldsmiths University, Political Economy Research Centre

Department for Communities and Local Government (2015) The English Indices of Deprivation 2015. London: The Department of Communities and Local Government

Disability, and Structural Stigma under Welfare Reform. Social Science and Medicine, 103, $76-83$

Dorling, D (2017) The Equality Effect. London, New Internationalist

Ellis, M (2017) Public sector workers doing $£ 11$ billion in unpaid overtime every year. Daily Mirror 24 July 2017

Eurobarometer (2015) Public Opinion in the European Union. Standard Eurobarometer 83: First Results. Brussels: European Commission

Ferguson, I, Ioakimidis, V and Lavalette, M (2017) Global Social Work in a Political Context: Radical perspectives. Bristol: Policy Press

Fitzpatrick, S., Bramley, G., Sosenko, F., Blenkinsopp, J., Johnsen, S, Littlewood, M. et al. (2015) Destitution in the UK. York: Joseph Rowntree Foundation

Garside, J. (2015) Recession rich: Britain s wealthiest double net worth since crisis. The Guardian, 26 April

Garside, J (2016) Hunger pains. Bristol: Policy Press

Hamilton, S (2017) UK Workers Worse off than pre-crisis as Generational Gap Opens. Bloomberg 10 Jan 2017 www.bloomberg.com/news/articles/2017-01-10/u-k-workersworse-off-than-before-financial-crisis-ons-says

Harman, C (2009) Zombie Capitalism. London: Bookmarks

Harrop, A., and Reed, H. (2015) Inequality in 2030. Fabian Policy Report. London: Fabian Society

Hastings, A., Bailey, N., Besemer, K., Bramley, G., Gannon, M., and Watkins, D. (2015) Coping with the cuts? Local government and poorer communities. York: Joseph Rowntree Foundation Hills, J. (2015) Good Times, Bad Times: The Welfare Myth of Them and Us. Bristol: Policy Press Institute for Fiscal Studies (2015) Recent Cuts to Public Spending www.ifs.org.uk/tools_ and_resources/fiscal_facts/public_spending_survey/cuts_to_public_spending (accessed 8 Aug 2017)

Jensen, T., and Tyler, I. (2015) Benefit Broods: The cultural and political crafting of antiwelfare commonsense. Critical Social Policy, 35, 4, 470-491

Lansley, S., and Mack, J. (2015) Breadline Britain: The rise of mass poverty. London: Oneworld McNicoll, A. (2014a) Rise in Mental Health Act detentions as NHS bed availability drops, 
Community Care, 31 October

McNicoll, A. (2014b) Mental Health Act detentions rise by 10 per cent, Community Care, 23 October

McNicoll, A. (2015) Mental health trust funding down 8\% from 2010 despite coalition's drive for parity of esteem, Community Care, 20 March

Mendoza, K-A. (2015) Austerity: The demolition of the welfare state and the rise of the zombie economy. Oxford: New Internationalist Publications

Meyer, H. and Stewart, H. UK house prices: 4.5\% rise in 2015 sparks calls for policy intervention. The Guardian, 30 December

New Economics Foundation (2016) The Financialisation of UK Homes: The housing crisis, land and the banks. London: NEF

Office for National Statistics (2015) Main Results from the Wealth and Assets Survey: July 2012 to June 2014. London: ONS

Office for National Statistics. (2014) Analysis of Employee Contracts that do not Guarantee a Minimum Number of Hours. London: ONS

RCPsych (2011) Do the Right Thing: How to judge a good ward. Ten standards for adult in-patient mental healthcare. Occasional Paper OP79. London: Royal College of Psychiatrists

Robbins, G (2017) There s No Place: The American housing crisis and what it means for the UK. London: Red Roof

Roberts, M (2016) The Long Depression. Chicago: Haymarket

Ryan, F (2017) Whether its teachers' pay or disability payments - the freeze is chilling. The Guardian 13 July. www.guardian.co.uk/commentisfree/2017/jul/13/public-sectorteachers-pay-benefits-freeze-carers-disabled-hardworking-britain (accessed 30 August 2017)

Stewart, H (2015) British households still $£ 500$ a year worse off than before the financial crisis. The Guardian 29 June. www.guardian.co.uk/money/2015/jun/29/british-households-500pounds-worse-off-than-before-financial-crisis-2008

Wright, D and Case, R Living standards squeeze tightens despite pay rises and tax cuts. Joseph Rowntree Foundation www.jrf.org.uk/press/living-standards-squeeze-tightensdespite-pay-rises-and-tax-cuts (accessed 8 August 2017) 